\title{
TCOM \\ The rise of skepticism in Spanish political and digital media contexts
}

\section{Lorena Cano-Orón, Isabel Mendoza-Poudereux and Carolina Moreno-Castro}

\begin{abstract}
Currently in Spain, there is a political and social debate over the use and sale of homeopathic products, which is promoted mainly by the skeptical movement. For the first time, this issue has become significant in political discourse. This study analyzes the role that homeopathy-related stories are playing in that political debate. We analyzed the viewpoints of headlines between 2015 and 2017 in eight digital dailies $(n=1,683)$, which published over 30 stories on homeopathy during the three-year study period. The results indicated that the stance on therapy's lack of scientific evidence gained ground during the period studied.
\end{abstract}

Keywords

DOI

Introduction
Health communication; Representations of science and technology; Science and media

https://doi.org/10.22323/2.18030201

Submitted: 23rd June 2018

Accepted: 14th January 2019

Published: 14th June 2019

During the last triennial period, there have been proactive movements in some western countries, promoted by scientific and regulatory institutions, to stop national health systems from financing homeopathy treatments due to a lack of scientific evidence. Homeopathy is deemed a complementary or alternative therapy because its efficacy has not been scientifically proven [Gibson, 2018; Vithoulkas, 2017; Fisher, 2017; Ministerio de Sanidad, Política Social e Igualdad, 2011], and when it has been proved, its effectiveness is no greater than the placebo effect [Cucherat et al., 2000; Howe, Goyer and Crum, 2017; Mathie et al., 2017; Loeb et al., 2018; Zion and Crum, 2018]. Hence, homeopathy is considered to be a practice based on theoretical principles which are not backed by science, which is why it is also called a "pseudoscience" or "facsimile science" [Oreskes, 2017].

In Spain, this treatment is legal if prescribed by a health professional, although, as with other alternative therapies, there is no specific regulation on the required training of therapists. The regulated sale of homeopathic products is a special case; this has always been restricted to pharmacies, where homeopathy has gradually 
carved out a niche for itself [Pray, 2006]. In Spain, homeopathic products are not sold in supermarkets or hypermarkets, as opposed to food supplements based on vitamins, minerals or herbal mixtures, which are. For many years, homeopathic products were marketed in pharmacies as medicines. At the end of 2017, however, the Spanish Agency of Medicines and Medical Devices turned down the license applications of the latest homeopathic products registered as such in Spain. Nevertheless, their sale was not restricted. At the time, there was no national legislation allowing homeopathic products to be registered as medicines. Although the skeptics celebrated the measure as a victory, it was to be short-lived; in April 2018, the Spanish government finally regulated homeopathic products as medicines. The explanation it gave was the need to harmonize national legislation with the European Directive in this regard. ${ }^{1}$ Notwithstanding, the Health Minister herself publicly pledged that the government would launch communication campaigns aimed at informing citizens about the lack of therapeutic evidence supporting the effectiveness of homeopathy [Salas, 2018].

Spanish politicians have come out against these unconventional therapies. Indeed, a Spanish Euro-parliamentarian requested the European Commission (hereafter, EC) to revise the directive and to stop calling homeopathy "medicine" [Cabezón, 2018]. The EC's response was as follows:

\begin{abstract}
EU legislation on homeopathic medicines was introduced in 1992 with the aim of ensuring their quality and safety whilst at the same time providing a clear indication of their homeopathic nature. At the time of adoption of the legislation, it was considered that despite the differences in recognition between Member States, consumers across the EU should be adequately protected if they choose to use homeopathic medicines [Andriukaitis, 2018].
\end{abstract}

Thus, whereas the EC's standpoint is to offer guarantees for the safety of homeopathic products, in Spain there is a latent debate on the regulation of homeopathy that, whenever the issue is aired by politicians, leads to social debate and breaking news. It is interesting to note that, since 2017, thanks to a nonbinding legislative proposal on pseudoscience, the country's four main political parties have shared the same stance: there is no scientific evidence to support complementary and alternative medicine (CAM) and, therefore, it cannot receive public funding or be included in the public health system. They have even come out against pseudoscience and in support of the need to monitor these practices. Therefore, in Spain there is, politically speaking, no artificial controversy [Ceccarelli, 2011; Ceccarelli, 2013]. In other words, politicians have admitted that the effectiveness of homeopathy is not a "scientific" debate because there is a clear consensus within the scientific community on the absence of reliable evidence supporting the effectiveness of homeopathic remedies; however, this is a relevant political issue that concerns governance.

Although the use of homeopathy in Spain is limited compared with other alternative therapies - only $5 \%$ of the population are homeopathy users [Cano-Orón, Mendoza-Poudereux and Moreno-Castro, 2018, in press; Centro de Investigaciones Sociológicas, 2018] — the skeptical movement's campaign against

\footnotetext{
${ }^{1}$ European Council Directive 92/73/EEC https: / / eur-lex.europa.eu/legal-content/EN/TXT/HTML/?uri=CELEX:31992L0073.
} 
homeopathy has gained momentum in recent years [Cano-Orón, 2018, submitted for publication]. This type of activism, which is also present in countries such as the U.K. and Australia [Caldwell, 2017; Brosnan, 2015; Flatt, 2013; Chatfield, Partington and Duckworth, 2012], has been promoted by civil society itself to discredit these therapies. The skeptical movement's discourse and activism have had social (the closure of various postgraduate courses taught at Spanish universities, as well as lobbying public institutions to ban lectures on pseudotherapies in their facilities), political (political parties unanimously agreeing to reject pseudotherapies), media (social media users bringing pressure to bear on journalists to get them to support the scientific perspective) and economic consequences (the fall in sales of homeopathic products).

Regarding the use of homeopathy in Spain, several facts are particularly striking in terms of the user profiles and information channels used to access information about treatments [Cano-Orón, Mendoza-Poudereux and Moreno-Castro, 2018, in press]. Friends and acquaintances, who may also be described as the patient's "lay referral network" [Evans et al., 2007], were the most consulted source, followed by the Internet $(28.2 \%)$. Nevertheless, this second information source can be inaccurate [Cole, Watkins and Kleine, 2016], the choice of reliable sources depending entirely on the user's level of scientific and digital literacy [Armstrong-Heimsoth et al., 2017]. Analyzing this source in an isolated manner could, therefore, lead to misinterpretations. In all likelihood, the personal experiences of family and friends have a greater influence on homeopathy users, who may then perform an active search on the Internet to find specific information on the treatment in question.

According to the latest Spanish Foundation of Science and Technology report [Fundación Española para la Ciencia y la Tecnología, 2017], 57.8\% of Spaniards obtain information about science and technology on the Internet, specifically social networks (43\%) and general digital media (34\%). Due to the general disregard for homeopathy in Spain, and taking into account that homeopathy consumers have found in the Internet an important information source, this study has the following objectives: (a) to quantify headlines of homeopathy-related stories published during the three-year study period; (b) to classify the story coverage tone (equidistant, skeptical or neutral) of the phenomenon; and (c) to identify the predominant news genre used in its coverage.

The study of the coverage of homeopathy by means of analyzing the headlines of digital dailies during a three-year period will allow us to obtain some indicators on their stance on the issue. Outcomes could help in identifying if these stances could be an obvious influence on public and political debates, i.e., whether there is any synchronicity in the analyzed period among the informative tone of digital dailies, the campaigns of the social movements' anti-homeopathy and the political decisions taken by the government.

Health journalism and pseudoscience
Science journalism, especially the kind specializing in health-related topics, has a great responsibility toward citizens, because "it does not merely transmit information, but participates in establishing the frames and narratives through which knowledge about health medicine is understood and circulated" [Hallin and Briggs, 2015, p. 95]. When dealing with news stories about pseudoscientific 
therapies, such as homeopathy, reiki and acupuncture, it is essential to identify how information is presented [Nissen et al., 2013].

In a meta-analysis of the media coverage of CAM, Weeks and Strudsholm [2008] found that, by and large, its tone was clearly positive depending on the country. More recent studies of the media treatment of CAM in other countries obtained similar results [Lavorgna and Di Ronco, 2017; Dong and Chan, 2016; Lauricella, 2016; Yel, 2014; Dunne and Phillips, 2010], although skeptical discourse is apparently gaining ground [Rowlands, 2015; Flatt, 2013; Lewis, Orrock and Myers, 2010].

\section{Media coverage of homeopathy}

In the specific case of homeopathy, Steuter [2001] discovered that the coverage of homeopathy in newspapers and magazines in the U.S.A., Canada, Australia, New Zealand, India and the U.K. was mostly neutral and without "bias and distortion" [Steuter, 2001, p. 4]. In light of this finding, it was understood that their point of view or tone was favorable with respect to the effectiveness of homeopathy. Only $15 \%$ of the news stories analyzed in this study presented homeopathy as "junk science." In contrast, more recent studies reveal a more critical media coverage of the topic:

- According to a study conducted by Steuter [2010], the homeopathy-related news stories published in English-language dailies in Canada, the U.S.A., the U.K., Australia, New Zealand and India, over a 10-year period (1998-2008), were mainly neutral (39\%) and positive (38\%), while more skeptical coverage, characterized by a negative point of view or tone (15\%) or "oppositional balance" (8\%), was not as commonplace. On the whole, the study confirmed that the media coverage of homeopathy was similar in all these countries, with the only exceptions being the U.K., for exceeding the positive mean threshold, and the U.S.A., where a greater number of skeptical stories were published.

- In the U.K., two studies quantitatively analyzed the state of the question. The first, conducted by Escribà-Sales, Cortiñas-Rovira and Alonso-Marcos [2015], compared the situation in the U.K. with that in Spain by analyzing The Guardian, The Times and The Daily Telegraph from 2009 to 2014, during which it was claimed that the homeopathy-related coverage of these U.K. media outlets was mostly negative $(71.1 \%$, versus $17.1 \%$ in favor and $11.8 \%$ ambivalent). The second study, carried out by Caldwell [2017], established 2007 as a critical juncture. Specifically, it pointed to the article that David Colquhoun - a university professor and leader of the skeptical campaign against homeopathy in the U.K. - published in Nature against the master's degree in Homeopathy as a turning point in the media coverage of homeopathy. Articles about university courses in homeopathy had been hitherto neutral or positive, but as of 2007 most coverage was negative.

- In Spain, Escribà-Sales, Cortiñas-Rovira and Alonso-Marcos [2015] analyzed five dailies (El País, El Mundo, ABC, La Vanguardia and El Periódico de Catalunya) between 2009 and 2014, concluding that, in general, the effectiveness of homeopathy was clearly challenged in $50 \%$ of the cases ( $25.7 \%$ in favor and $24.3 \%$ ambivalent). The authors highlighted the coverage 
of El Periódico de Catalunya and La Vanguardia, stating that while the former tended to adopt a position in favor of this therapy, the latter was ambivalent in most cases. In terms of the most prevalent genre, news stories were the most numerous, although El Periódico de Catalunya was again singled out for having published more opinion pieces than news stories.

We could be forgiven for thinking that the type of approach employed by these dailies is linked to the conclusions of scientific studies published in peer-reviewed journals. However, the data suggest otherwise. Caulfield and DeBow [2005] analyzed the results and the tone of homeopathy-related papers in PubMed, detecting that the majority employed neutral or positive language when discussing the results, which were mostly negative in conventional journals and positive in their counterparts specializing in CAM; this was attributed to publication-related bias.

Therefore, in addition to the literature produced by academia, when writing news stories, journalists play a central role in constructing frames [Hallin and Briggs, 2015; Stocking and Holstein, 2009] and "can contribute to the public's mental picture of health, including issues related to controversial CAM such as homeopathy" [Arendt, 2016, p. 18]. In Germany, journalists' attitudes toward homeopathy have become polarized between two extremes: positive and negative. Those showing more favorable attitudes toward homeopathy are "women journalists, journalists working in senior positions and journalists working on health-related content" [Arendt, 2016, p. 20]. In Spain, a study was also performed on this issue, in this case focusing on science journalists. Here, polarization comprised two factions: one that felt that news about pseudoscience should have no place in the press, and the other holding that it should be covered, but only to inform and warn society [Cortiñas-Rovira et al., 2015].

\section{Media effects of digital news}

From a communication theory perspective, recent studies indicate that in the current digital media ecosystem media impact is minimal [Bennett and Iyengar, 2008; Bennett and Iyengar, 2010; Shehata and Strömbäck, 2013], compared to that of agenda-setting or framing [Lazarsfeld, Berelson and Gaudet, 1944; Scheufele, 2000; Scheufele and Tewksbury, 2006], since persuasion and the transmission of certain frames have the sole effect of strengthening what audiences are already willing to perceive [Sunstein, 2002; Pariser, 2011], namely, the so-called "selective exposure" or "confirmation bias" [D'Angelo, 2018].

However, the testing of these theories in the science communication field has yielded different results, demonstrating that "online users interact differently with science information than with political information" [Jang, 2014, p. 161]. For example, Brewer [2013] addressed the construction of scientific authority, claiming that specific media messages can influence citizens' beliefs, in this case about paranormal investigations. Jang [2014], when analyzing the phenomenon of "selective exposure" to controversial scientific issues in the digital realm, discovered that, in these cases, the respondents did not follow the "confirmation bias" pattern, but paid more attention to news that diverged from their existing knowledge. 
Similarly, Chang [2015] underscored the respondents' greater level of skepticism, because information that contradicted or clashed with their existing knowledge was viewed with suspicion and led to confusion. Knobloch-Westerwick et al. [2015], after analyzing how exposure to online science information affects citizens' attitudes, obtained results that differed slightly from previous findings. The authors did indeed demonstrate the respondents" "confirmation bias" in regards to several scientific issues, although they qualified such evidence; unlike theories that suggest that citizens isolate themselves from divergent opinions by entering echo chambers [Sunstein, 2002] or filter bubbles [Pariser, 2011], the respondents consumed information that contradicted their beliefs, albeit in a very modest fashion.

As for the media impact on the public perception of CAM, Caldwell [2017] reveals how, since the launching of the skeptical media campaign against homeopathy, the media have tended to criticize its teaching at U.K. universities. For its part, the U.K. government has gone from supporting this alternative therapy to demanding evidence of its effectiveness. This specific case would confirm the influence, although not at a personal/citizen level (the taking or not of homeopathic pills), but at an institutional and social one.

Objectives and hypothesis
The objectives of this study are the following. On the one hand, to quantify how often homeopathy is present in digital dailies and to check if the peaks in publication frequency concur with related political events, and on the other hand, to identify the dominant slant or tone of the headlines of homeopathy-related stories and observe their evolution during the analyzed period (qualitative study).

These objectives will be carried out via the main hypotheses of our study: the pattern and flow of publication peaks in the digital dailies analyzed could be connected to establishment politics and skeptical movement agenda issues.

What is understood here as a political issue is a public debate or a political statement regarding the regulation or governance of the health system, or policies implemented in this respect, whereas social development refers to activities relating to activism, education, consumption, reports, surveys, etc.

The corpus comprises all the headlines of news items containing the word "homeopathy," published in the 391 nationwide digital media outlets figuring in the MyNews database, during a three-year period (2015-2017). Although 2,545 news items were collected, after manual cleaning to remove those that either did not actually contain the term "homeopathy" or, when they did, homeopathy was neither the main nor a peripheral issue, this number was reduced to 1,673 news stories distributed as follows: 320 items in 2015; 532 items in 2016; and 825 items in 2017.

The headlines were then analyzed following Westall [2015] because, according to Lozano Ascencio, Piñuel Raigada and Gaitán Moya [2010], they are the most critical information link between media outlets and their audiences. Moreover, a headline tends to summarize the body copy and offers journalists the chance to indicate from which perspective the story has been narrated. Taking into account 
the current digital ecosystem, in which people have access to a great deal of information but no time to read it all, they are now more likely to read headlines than body copy, if they read those at all. According to Lozano Ascencio, Piñuel Raigada and Gaitán Moya [2010], visual zapping on dailies, which includes reading most of the headlines, is now the most prevalent reading method. For many, reading headlines is a good way of keeping abreast of the news and being well-informed. Thus, their analysis reveals the discursive sphere that is most accessible to audiences and whose narrative is the most influential.

In this study, the headline of each story was analyzed, including the platform on which it had been posted, the date of publication, the headline's slant or tone (favorable, equidistant, skeptical or neutral), and the news genre (information, opinion, interview or others). To identify the tendency of the homeopathy-related news stories contained in the corpus, a manual analysis was performed on their headlines' tone, which was classified as follows:

FAVORABLE: those headlines representing CAM in general, or homeopathy in particular, as effective therapies and/or coinciding with their advocates' defense of natural medicine and the patient's right to choose, e.g., "Well, homeopathy worked for me" (El País, 09/22/2015).

NEUTRAL: those headlines whose body copy mentioned homeopathy, although neither this term nor CAM appeared in the headline itself or, when it did, without addressing the controversy on its effectiveness, e.g., "Marta Galipienzo, the new president of the official pharmacy school of Navarra" (La Vanguardia, 02/23/2015).

EQUIDISTANT: those headlines that explicitly covered the controversy on the effectiveness or use of homeopathy or CAM, but nonetheless took no favorable or skeptical approach, in addition to those which, even after taking a stand on the issue, were couched in ambiguous terms, giving rise to doubts about their stance, e.g., "Homeopathy and debate" (El Mundo, 03/04/2016).

SKEPTICAL: those headlines that painted a negative picture of homeopathy or CAM and/or referred to it and the discourse in favor of natural medicine in a derogatory fashion, e.g., "I prefer to give Pez candies to my children before homeopathy (at least they have cool vending machines)" (20Minutos, 05/22/2015).

These four categories have been adapted from those used by Escribà-Sales, Cortiñas-Rovira and Alonso-Marcos [2015], albeit renaming their "ambivalent" category "equidistant" and adding the "neutral" category. The authors had discarded the possibility of using the latter because it had no bearing on their research topic. Nevertheless, we believe that it is interesting to measure the number of news stories mentioning homeopathy (in some part of the body copy) but without focusing on the topic, insofar as this offers a broader idea of the therapy's visibility in the Spanish media.

To validate the data coding method, two researchers held several meetings to agree on the characteristics of each category. Subsequently, Cronbach's alpha was used to assess the internal consistency coefficient (0.904) of a random sample of $20.6 \%$ ( $n=$ 344). 
The headlines of the main Spanish digital dailies - specifically, those with the largest readership [Negredo, Vara and Amoedo, 2017] that had published over 30 news stories on homeopathy during the three-year study period — were analyzed in depth (Table 1). Since the Digital News Report [Negredo, Vara and Amoedo, 2017] ranks "Regional or local newspaper websites in general" as the third most consulted source, El Periodico de Catalunya was also included to this category due to the number of news stories it had published (50 during the three-year period) and because it has been studied previously [Escribà-Sales, Cortiñas-Rovira and Alonso-Marcos, 2015]. In addition to the viewpoint used, this analysis included the type of story (data retrieved from the database and verified), i.e., information, opinion, interview or others, and the publication frequency during the study period.

Table 1. The most read digital dailies* [Negredo, Vara and Amoedo, 2017] publishing over 30 homeopathy-related news stories (2015-2017).

\begin{tabular}{|lcr|}
\hline Digital daily & Audience share & No. of stories \\
\hline El País & $29 \%$ & 112 \\
El Mundo & $22 \%$ & 43 \\
El Periódico de Cataluña & $18 \% * *$ & 50 \\
20Minutos & $17 \%$ & 41 \\
El Confidencial & $16 \%$ & 66 \\
Eldiario.es & $16 \%$ & 30 \\
ABC online & $11 \%$ & 69 \\
La Vanguardia & $11 \%$ & 64 \\
\hline Most visited online dailies per week* & \\
Regional or local digital daily share** & \\
The Spanish Internet user sample accounted for $\mathrm{n}=2,006$ surveys.
\end{tabular}

Pearson's $\chi 2$ test was used to check the correlations between the information trends and the most read digital dailies, the genre (information, opinion, interview or others), and the date of publication.

Results

Throughout the three-year study period, the headlines of these eight digital dailies dealing with homeopathy were, on the whole, skeptical (40\%) or neutral (33\%), while favorable $(15 \%)$ or equidistant $(12 \%)$ approaches were less frequent. However, the results by year (Figure 1) reveal an evolution in both the news treatment of homeopathy and the number of news stories published on the subject. While in 2015, 320 homeopathy-related news stories were published and the most prevalent slant on headlines was neutral (44\%), in 2016 their number increased to 532 , with the skeptical approach now being more frequent $(41 \%)$ in headlines. Lastly, in 2017, the number of stories almost tripled (821), with the skeptical approach gaining further ground (44\%) in headlines. In light of the results of Pearson's $\chi 2$ test, there was a significant correlation $(\chi 2=33.384 ; \mathrm{p}=0.000 ; \mathrm{n}=$ $1,673)$ between the year of publication and how homeopathy-related headlines were addressed.

The temporal distribution of the stories (Figure 2) reveals a similar pattern over the three years, with August being the month when these were fewer and March and 


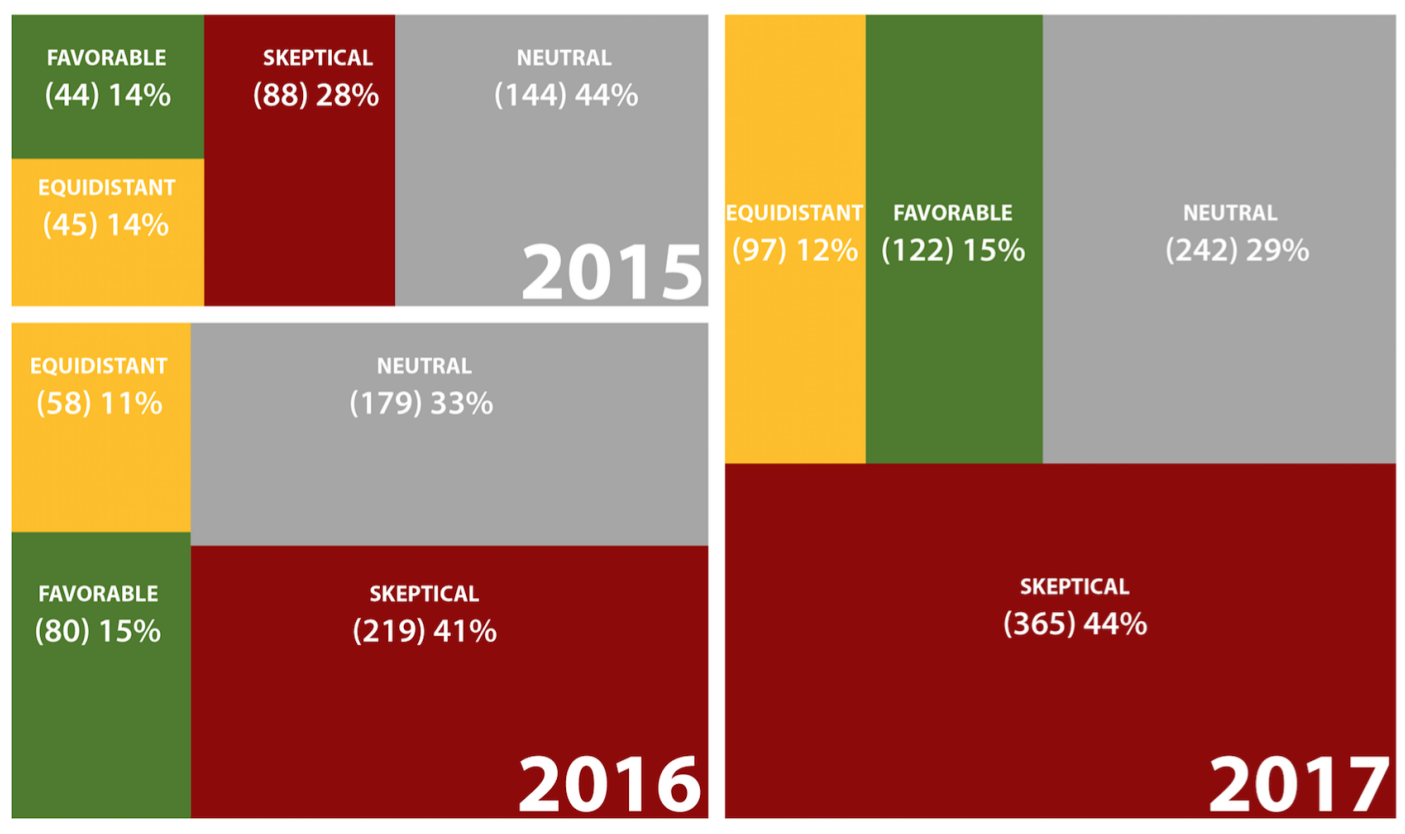

Figure 1. Headlines of homeopathy-related stories by viewpoint and by year of publication. The size of each subdivision correlates directly with the number of stories published per year (321 in 2015; 536 in 2016; and 826 in 2017). All percentages refer to the year of publication.

June those when the largest number was published. Figure 2 shows the developments that the media deemed the most newsworthy:

- In 2015, the largest number of stories on homeopathy was published in April and coverage of headlines was mostly neutral. Specifically, the peak in media coverage coincided with the announcement of the construction of a private hospital in Madrid that would offer homeopathy services (Figure 2, A).

- In 2016, the largest number of stories was published in March and coverage of headlines was mainly skeptical. The increase in news during this month coincided with the closure of the master's degree program in Homeopathy offered by the University of Barcelona (Figure 2, B).

- In 2017, there was a peak in coverage between April and July, due to the following developments:

- World Homeopathy Day took place on April 10. Skeptical groups took advantage of this to launch social media awareness campaigns (Figure 2, C). Furthermore, the Spanish Foundation for Science and Technology report, [Fundación Española para la Ciencia y la Tecnología, 2017], revealing that half of the respondents believed in homeopathy, was also published that month (Figure 2, D).

- In May, the Colleges of Physicians of Las Palmas and Madrid closed their homeopathy sections. Additionally, the death in Italy of a child with otitis, who had been treated exclusively using homeopathy (Figure 2, a), received a great deal of media coverage.

- In June, the College of Physicians of Barcelona began proceedings against five doctors for publicly stating that they had cured cancer with 
alternative therapies (Figure 2, b). Similarly, the Royal Academy of Pharmacy released a statement warning that homeopathy posed a health risk to citizens (Figure 2, c).

$\square$ In July, the month with the largest number of stories, the regional health minister for the Valencian Community issued a statement in which she said that homeopathy was not medicine and urged the central government not to recognize it legally as such (Figure 2, d).

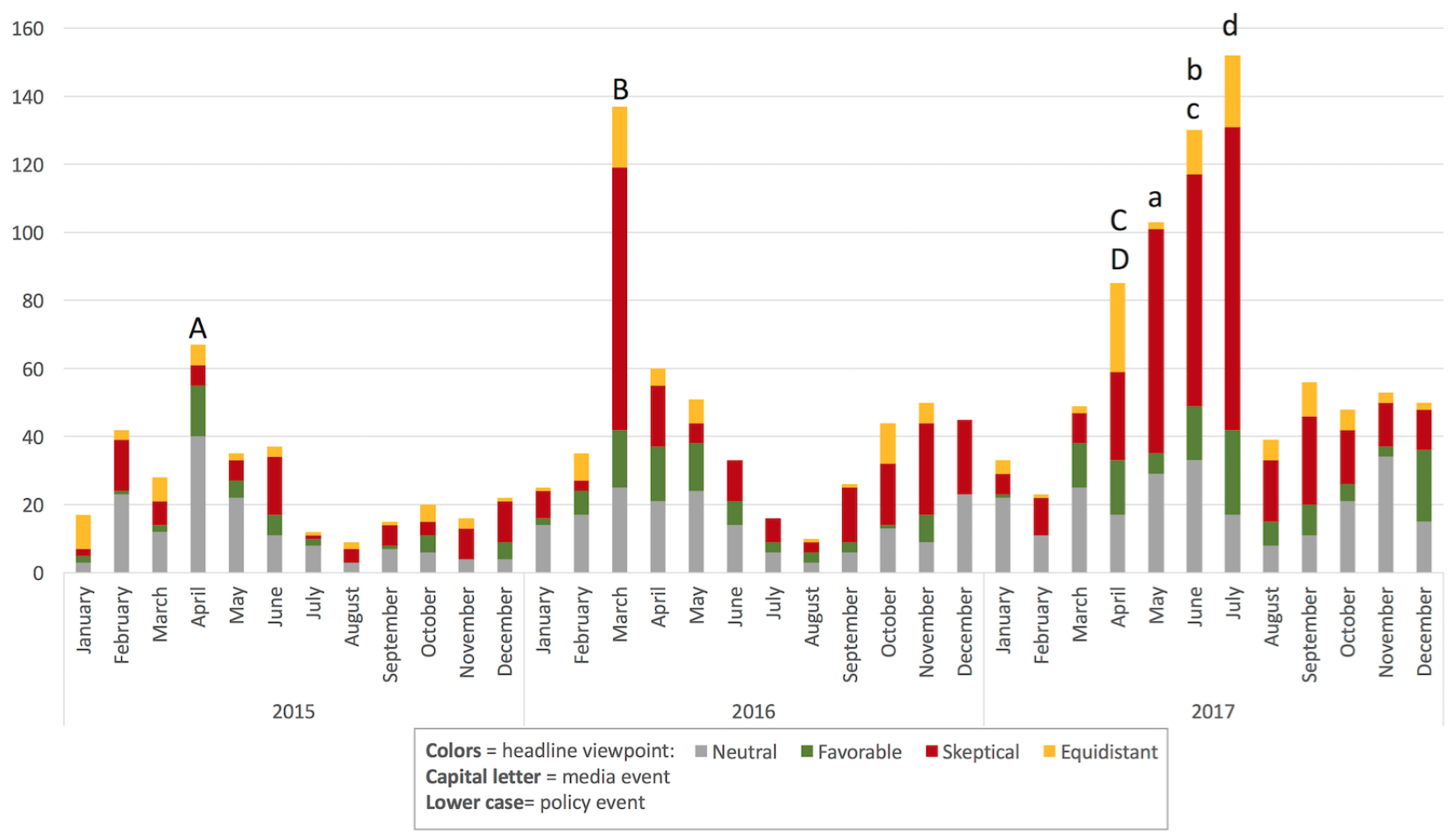

Figure 2. Number of news stories and their news treatment of homeopathy from 2015 to 2017. Uppercase letters indicate specific newsworthy events, while lowercase letters indicate policy-related developments, as described above.

Nevertheless, during this three-year period there were a number of policy developments that, despite having a great impact on Spanish law, did not receive as much coverage as the ones described above. For instance, in February 2017 the political party Ciudadanos (liberals) put forward a nonbinding legislative proposal with the aim of obliging medical practitioners to report colleagues who resorted to alternative therapies. In addition, in September 2017, the parliamentary Health Committee rejected the proposal and the Cabinet decided to delegate responsibilities and powers of decision in this regard to the country's regional governments.

An analysis of the eight most-read digital dailies publishing the largest number of homeopathy-related news stories reveals that the genre most used was information (Figure 3). However, El País and El Periódico de Catalunya stand out because they published the greatest number of opinion pieces on the subject, the latter, above all, for publishing more opinion pieces than news stories. In this connection, it should 
also be noted that $A B C$ only published news stories. As for interviews, they were generally few and far between.

Except for El Confidencial and La Vanguardia, publication frequency increased over the three-year study period, exponentially in some cases (from 2015 to 2016 in the case of $A B C$ and El Periódico de Catalunya, for example), with the exception of 20Minutos and Eldiario.es, which in 2016 published fewer stories than in 2015 and 2017.
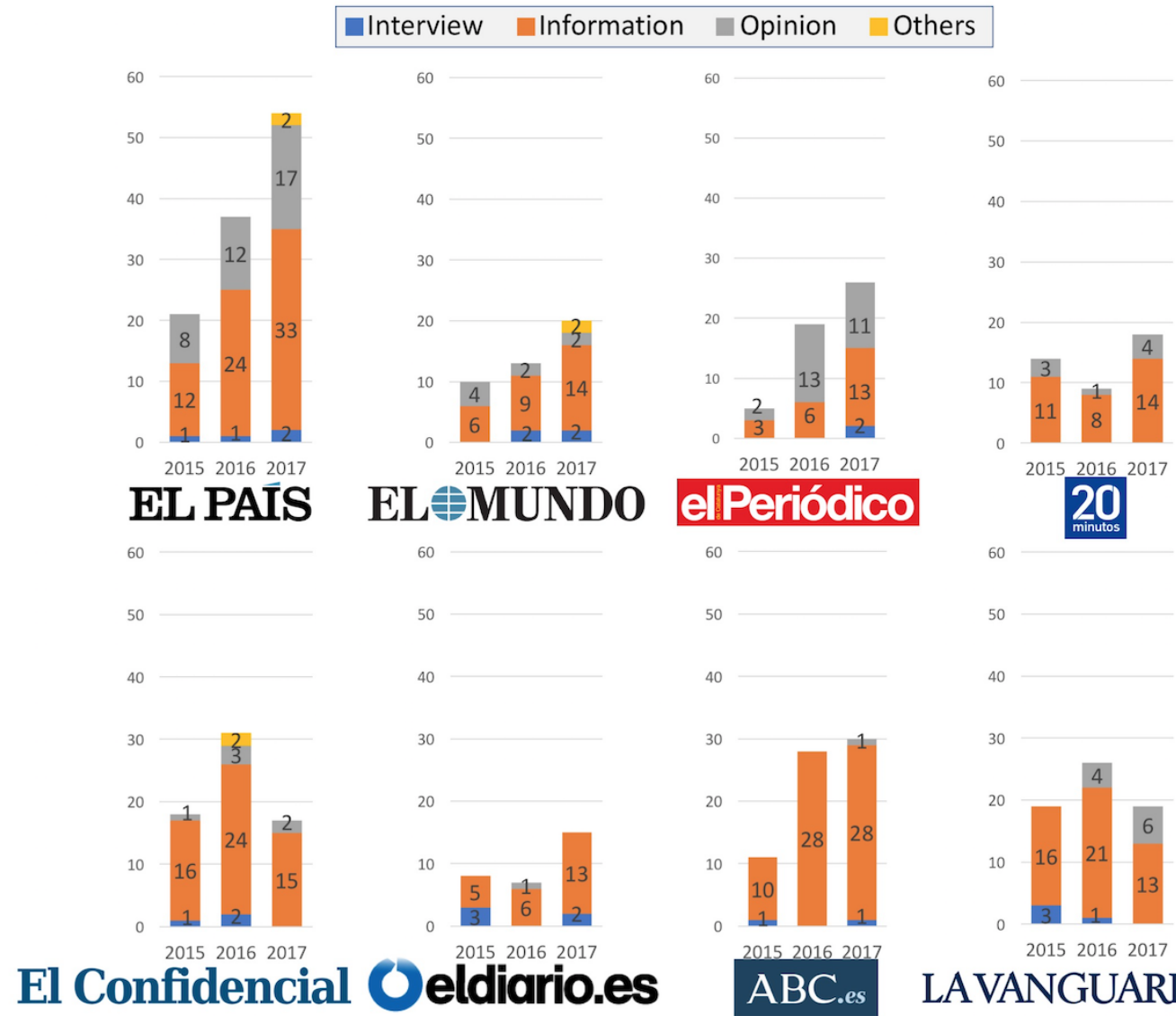

LAVANGUARDIA

Figure 3. Type of news stories published in the eight digital dailies.

Second, regarding the classification of the headlines' treatment of tone (Figure 4), El País and El Confidencial expressed theirs in skeptical terms. During the three-year period, as a matter of fact, skeptical headlines became more commonplace, to the detriment of favorable ones, with the exception of 20Minutos, which published a higher number of favorable headlines in 2017. The case of El Periódico de Catalunya deserves special mention in this regard, as it changed its stance from not publishing any equidistant or skeptical headlines in 2015, to publishing mainly skeptical ones in 2017.

According to the results of Pearson's $\chi 2$ test, there was a significant correlation between the eight digital dailies and how they addressed headlines on homeopathy-related stories $\left(\chi^{2}=40.886 ; \mathrm{p}=0.006 ; \mathrm{n}=475\right)$ and the news genre $\left(\chi^{2}\right.$ $=91.042 ; \mathrm{p}=0.000 ; \mathrm{n}=475)$. However, there was no significant correlation among the dailies, the news genre and the viewpoint $\left(\chi^{2}=6.358 \mathrm{p}=0.704 ; \mathrm{n}=475\right)$. 


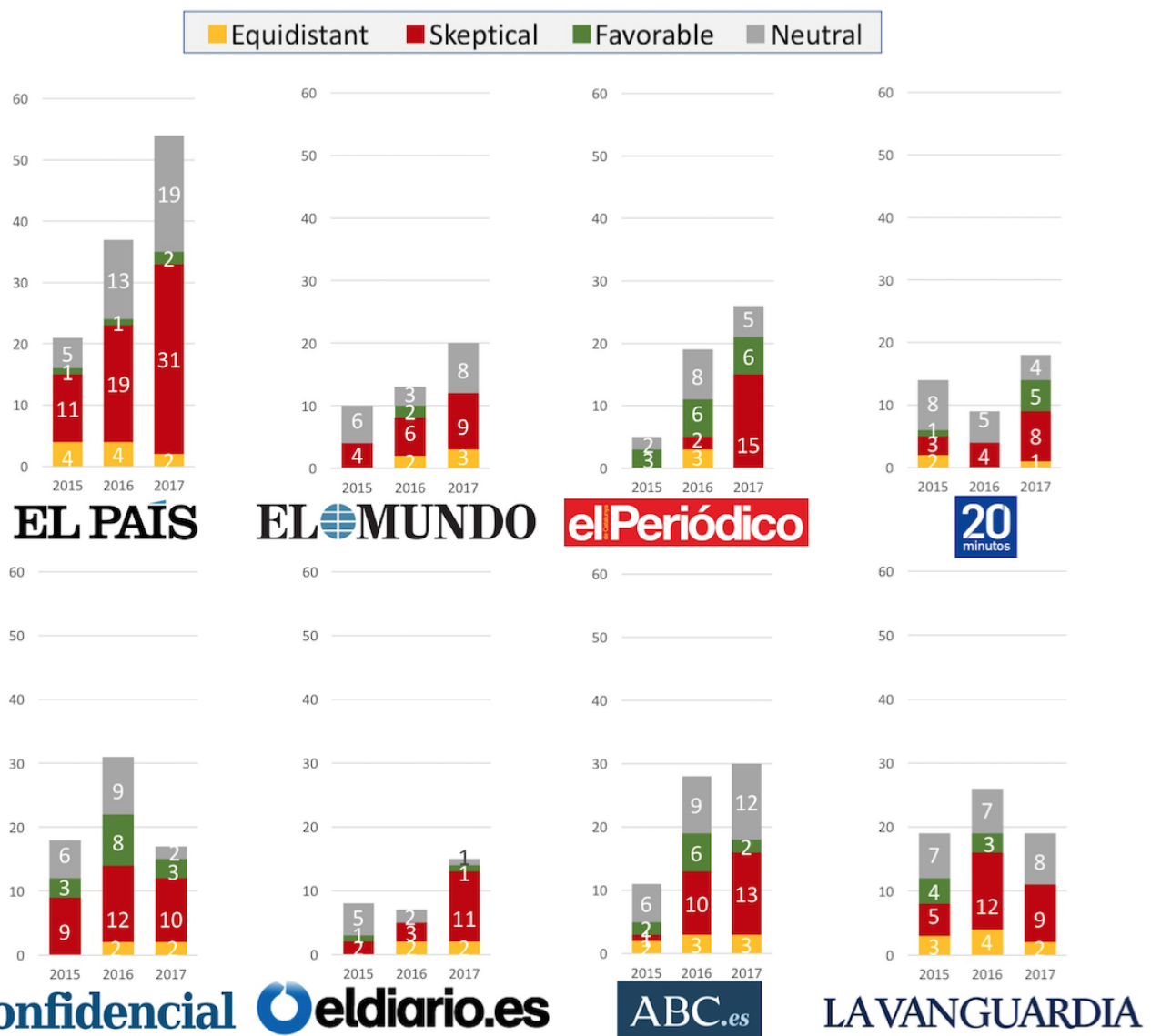

Figure 4. Headlines on homeopathy in the eight digital dailies.

The correlation between the news genre and how headlines were addressed was also analyzed in the study database, but no statistically significant correlations were found $(x 2=8.922 ; p=0.444)$. It was decided not to perform a comparative analysis of all the digital dailies and their individual viewpoint because some had published few stories, which would have invalidated the statistical conclusions.

It is interesting to note the increase in the number of homeopathy-related stories during the study period. For example, nearly as many stories were published in 2017 as in 2015 and 2016 together. The conclusion that can be drawn from this is that in 2015 homeopathy was still a marginal topic for the media, whereas by 2017 it had become newsworthy. The fact that homeopathy has found its way onto the political agenda has increased public awareness of the issue. There is growing concern among the Spanish government and political establishment about the legal status of CAM, and a general consensus on the need to crack down on its practice in the public health system.

The viewpoint of headlines of homeopathy-related stories published in eight Spanish digital dailies from 2015 to 2017 tended to be skeptical (40\%), a tendency that increased over the period. For instance, this can be illustrated by comparing the treatment of headlines in April 2015 with that in April 2017, the month during which World Homeopathy Day takes place. While it received no media coverage in April 2015, it did indeed in April 2017, most headlines being skeptical. However, in 
terms of opinions or facts, information was still the most popular genre, coinciding with Escribà-Sales, Cortiñas-Rovira and Alonso-Marcos [2015], except in the case of El Periódico Catalunya, which published the greatest number of opinion pieces.

If the analysis of the slant or tone of headlines of homeopathy-related stories were restricted to those appearing in the five digital dailies (El País, El Mundo, ABC, La Vanguardia, and El Periódico de Catalunya) selected in a previous study [Escribà-Sales, Cortiñas-Rovira and Alonso-Marcos, 2015], the results for the period 2015-2017 would be $15 \%$ equidistant (i.e., ambivalent), 66\% skeptical and $19 \%$ favorable, out of a total of 316 stories. To obtain these results, the data corresponding to the neutral category not included in the study performed by Escribà-Sales, Cortiñas-Rovira and Alonso-Marcos [2015] were eliminated from the sample. Thus, it may be claimed that the media coverage of headlines of homeopathy-related stories was generally more skeptical (from $50 \%$ to $66 \%$ ) than favorable (from $25 \%$ to $19 \%$ ).

In their study, Escribà-Sales, Cortiñas-Rovira and Alonso-Marcos [2015] singled out La Vanguardia for its mainly ambivalent coverage from 2009 to 2014. In the period 2015-2017, 14\% of headlines of homeopathy-related stories appearing in this digital daily were equidistant, while most were skeptical (42\%). These data confirm the skeptical drift of the digital press. From 2009 to 2014 El Periódico de Catalunya, for its part, stood out for its position in favor of this alternative therapy [Escribà-Sales, Cortiñas-Rovira and Alonso-Marcos, 2015], but during the period 2015-2017 its stance changed abruptly, with $57 \%(15 / 26)$ of the headlines of homeopathy-related stories that it published in 2017 taking a skeptical line.

There is no scientific evidence that homeopathy is more effective than placebos. Clinical trials and meta-analyses have been performed to discover whether its therapeutic effect on any number of pathologies is greater than in placebo control groups. Strictly speaking, nor can it be regarded as harmless when used as a substitute for conventional treatments. Quite the contrary, it can endanger the health of patients who stop taking scientifically endorsed drugs in favor of homeopathic pills with no proven therapeutic effects.

On the other hand, the regulations governing the marketing of homeopathic products and the professional training of therapists differ from country to country. For example, EU Member States such as France and Germany have included homeopathy in their health systems, as well as introducing specific official training courses for therapists. Lastly, from a business perspective, this alternative therapy could be considered a health fraud scam, since pills containing no active ingredient are being sold at high prices, solely on the strength of the supposed "water memory" effect.

Therefore, the study of the news coverage of homeopathy in digital dailies, which leaves its mark on social networks and other similar spaces, is an effective way of identifying its positive or negative bias at any given time. In relation to previous studies of the effects of media coverage on scientific issues [Brewer, 2013; Jang, 2014; Chang, 2015; Knobloch-Westerwick et al., 2015], it may be stated that the media legitimize scientific discourses and conceal or discredit those sources that defend homeopathy, which coincides with the situation described by Caldwell [2017] in the U.K. On the other hand, according to the studies performed by Chang 
[2015], Jang [2014] and Knobloch-Westerwick et al. [2015], individuals are interested in science news that contradicts, in some way, their existing knowledge. The fact that homeopathy sales have dropped, in the midst of this media vortex, and the indignation of the skeptical media coverage, points to a possible relationship between these two facts. Further studies should be conducted to explore this phenomenon.

Previous studies [Escribà-Sales, Cortiñas-Rovira and Alonso-Marcos, 2015] showed that $50 \%$ of the homeopathy-related stories published in five flagship Spanish digital dailies (El País, El Mundo, ABC, La Vanguardia, and El Periódico de Catalunya) were skeptical. A similar trend has been revealed in 391 headlines of homeopathy-related stories published in eight Spanish digital dailies during three years (2015-2017). Thus, it could be confirmed that the country's digital press is contributing to debunking homeopathy and building a public image against the practice. At the same time, the media's skeptical stance on homeopathy mirrored the central position in the agenda issues, which the political establishment defended during at least the last two years of this study. Hence, the pro-science stance of the eight digital dailies that questioned the effectiveness of homeopathy was intensified in Spain during the period analyzed, increasing the skeptical approach by $16 \%$, to reach $66 \%$ of the total number of the headlines published.

This skeptical perspective of the headlines coincided with (a) the agreement reached by the main Spanish political parties not to allocate public funding to CAM initiatives and to issue public statements underscoring the lack of scientific evidence supporting homeopathy; (b) a social debate on homeopathy, mainly promoted by the skeptical movement, as already noted, with the issue gradually attracting more media coverage; and (c) a drop in sales of homeopathic products due to lower demand [Vigario, 2017].

The eight Spanish digital dailies analyzed here shared a skeptical viewpoint in most of its headlines of homeopathy-related stories, contributing to spreading the idea that the sale of homeopathic products was a scam and tantamount to throwing one's money down the drain, due to the lack of scientific evidence supporting their effectiveness. In this sense, that dailies have been demanding that policymakers regulate these homeopathic products was appropriate to protecting and promoting public health. Therefore, not only did the media unite in a common cause with colleges of chemists, pharmacists and biologists, but scientists from other fields also entered the fray, lobbying the public administration to ban the sale of homeopathic products in pharmacies and to disavow medical practitioners who prescribed them. In light of the above conclusion, it is evident that dailies have been disseminating signals to public opinion about the end of the lack of the regulatory control of homeopathic treatments, at the same time as policymakers began to take measures to improve the governance of practitioners and consumers. Limitations of this work lie in its analytic assertions. Since the aim here was to analyze manually the homeopathy-related news stories published in 391 digital media outlets over a three-year period, it was only possible to focus on the headlines and not on the body copy. In addition, the possibility of performing a more meticulous content analysis on the remainder of the stories' elements was rejected in the end. 
In future research, it would be interesting to discover what the public and physicians think about homeopathic treatment and whether it is connected with media discourse, while also comparing these results with those obtained during the period coinciding with the social campaign against homeopathy launched in the U.K. and Australia. This would enable us to gauge whether the level of public rejection or lack of political and social legitimacy of homeopathy was a consequence of the media's endorsement of the views of the scientific community in this respect.

This paper is exploratory research of the project "Study, taxonomic and coverage of complementary, alternative, natural therapies on media and social networking. Ideas and values reported into the social imaginary" (CSO2014-57778-R), funded by the Spanish Ministry of Economy and Competitiveness and co-financed with FEDER funds from the European Commission.

\section{References}

Andriukaitis, V. (21st June 2018). Answer given by Mr. Andriukaitis on behalf of the Commission. Parliamentary questions. URL: http: / /www . europarl . europa. eu/s ides/getAllAnswers . do?reference=E-2018-002348\&language=EN (visited on 15th September 2018).

Arendt, F. (2016). 'Journalists' attitudes towards homeopathy: survey data from Germany'. Focus on Alternative and Complementary Therapies 21 (1), pp. 17-21. https://doi.org/10.1111/fct.12244.

Armstrong-Heimsoth, A., Johnson, M. L., McCulley, A., Basinger, M., Maki, K. and Davison, D. (2017). 'Good googling: a consumer health literacy program empowering parents to find quality health information online'. Journal of Consumer Health on the Internet 21 (2), pp. 111-124. https://doi.org/10.1080/15398285.2017.1308191.

Bennett, W. L. and Iyengar, S. (2008). 'A new era of minimal effects? The changing foundations of political communication'. Journal of Communication 58 (4), pp. 707-731. https://doi.org/10.1111/j.1460-2466.2008.00410.x.

- (2010). 'The shifting foundations of political communication: responding to a defense of the media effects paradigm'. Journal of Communication 60 (1), pp.35-39. https://doi.org/10.1111/j.1460-2466.2009.01471.x.

Brewer, P. R. (2013). 'The trappings of science: media messages, scientific authority and beliefs about paranormal investigators'. Science Communication 35 (3), pp. 311-333. https://doi.org/10.1177/1075547012454599.

Brosnan, C. (2015). “Quackery' in the academy? Professional knowledge, autonomy and the debate over complementary medicine degrees'. Sociology 49 (6), pp. 1047-1064. https://doi.org/10.1177/0038038514557912.

Cabezón, S. (26th April 2018). Revision of the designation of homeopathic substances as medicinal products under Directive 2001/83/EC. Parliamentary questions.

URL: http://www . europarl. europa. eu/sides/getDoc.do?pubRef=- //EP//TEX $\mathrm{T}+\mathrm{WQ}+\mathrm{E}-2018-002348+0+\mathrm{DOC}+\mathrm{XML}+\mathrm{VO} / / \mathrm{EN}$ (visited on 15th September 2018).

Caldwell, E. F. (2017). 'Quackademia? Mass-media delegitimation of homeopathy education'. Science as Culture 26 (3), pp. 380-407. https://doi.org/10.1080/09505431.2017.1316253. 
Cano-Orón, L. (2018, submitted for publication). 'A Twitter campaign against pseudoscience: the sceptical discourse on complementary therapies in Spain'.

Cano-Orón, L., Mendoza-Poudereux, I. and Moreno-Castro, C. (2018, in press). 'Perfil sociodemográfico del usuario de la homeopatía en España'. Atención Primaria. https://doi .org/10.1016/j.aprim.2018.07.006.

Caulfield, T. and DeBow, S. (2005). 'A systematic review of how homeopathy is represented in conventional and CAM peer reviewed journals'. BMC Complementary and Alternative Medicine 5 (1). https://doi.org/10.1186/1472-6882-5-12.

Ceccarelli, L. (2011). 'Manufactured scientific controversy: science, rhetoric and public debate'. Rhetoric E Public Affairs 14 (2), pp. 195-228. https://doi.org/10.1353/rap.2010.0222.

- (2013). 'Controversy over manufactured scientific controversy: a rejoinder to Fuller'. Rhetoric \& Public Affairs 16 (4), pp. 761-766. https://doi.org/10.1353/rap.2013.0050.

Centro de Investigaciones Sociológicas (2018). Barómetro de febrero 2018. Estudio n 3205. Madrid, Spain. URL: http://www.cis.es/cis/export/sites/default /-Archivos/Marginales/3200_3219/3205/es3205mar.pdf.

Chang, C. (2015). 'Motivated processing: how people perceive news covering novel or contradictory health research findings'. Science Communication 37 (5), pp. 602-634. https://doi .org/10.1177/1075547015597914.

Chatfield, K., Partington, H. and Duckworth, J. (2012). 'The place of the university in the provision of CAM education'. The Australian Journal of Homeopathic Medicine 24 (1), pp. 16-20.

Cole, J., Watkins, C. and Kleine, D. (2016). 'Health advice from Internet discussion forums: how bad is dangerous?' Journal of Medical Internet Research 18 (1), e4. https://doi.org/10.2196/jmir. 5051.

Cortiñas-Rovira, S., Alonso-Marcos, F., Pont-Sorribes, C. and Escribà-Sales, E. (2015). 'Science journalists' perceptions and attitudes to pseudoscience in Spain'. Public Understanding of Science 24 (4), pp. 450-465. https://doi.org/10.1177/0963662514558991.

Cucherat, M., Haugh, M. C., Gooch, M. and Boissel, J.-P. (2000). 'Evidence of clinical efficacy of homeopathy'. European Journal of Clinical Pharmacology 56 (1), pp. 27-33. https://doi.org/10.1007/s002280050716.

D'Angelo, P. (2018). Doing news framing analysis II. New York, NY, U.S.A.: Routledge.

Dong, D. and Chan, K. (2016). 'Authorization, rationalization and moral evaluation: legitimizing acupuncture in Hong Kong's newspapers'. Asian Journal of Communication 26 (2), pp. 114-132. https://doi.org/10.1080/01292986.2015.1089915.

Dunne, A. and Phillips, C. (2010). 'Complementary and alternative medicine: representation in popular magazines'. Australian family physician 39 (9), pp. 671-674.

Escribà-Sales, E., Cortiñas-Rovira, S. and Alonso-Marcos, F. (2015). 'La pseudociencia en los medios de comunicación: estudio de caso del tratamiento de la homeopatía en la prensa española y británica durante el período 2009-2014'. Panace@ 16 (42),pp. 177-183. 
Evans, M., Shaw, A., Thompson, E. A., Falk, S., Turton, P., Thompson, T. and Sharp, D. (2007). 'Decisions to use complementary and alternative medicine (CAM) by male cancer patients: information-seeking roles and types of evidence used'. BMC Complementary and Alternative Medicine 7 (1), p. 25. https://doi .org/10.1186/1472-6882-7-25.

Fisher, P. (2017). 'Homeopathy and intellectual honesty'. Homeopathy 106 (4), pp. 191-193. https://doi.org/10.1016/j.homp.2017.10.001.

Flatt, J. (2013). 'Critical discourse analysis of rhetoric against complementary medicine'. Creative Approaches to Research 6 (2), pp. 57-70.

Fundación Española para la Ciencia y la Tecnología (2017). VIII Encuesta de percepción social de la ciencia. URL: http://www .idi.mineco.gob.es/stfls/MICIN N/Cultura/FICHEROS/2017/Dossier_PSC_2017.pdf (visited on 30th May 2018).

Gibson, W. J. (2018). 'Homeopathy, western medicine and the discourse of evidence: negotiating legitimacy in a public online forum'. Current Sociology 66 (7), pp. 1013-1030. https://doi.org/10.1177/0011392118776354.

Hallin, D. C. and Briggs, C. L. (2015). 'Transcending the medical/media opposition in research on news coverage of health and medicine'. Media, Culture $\mathcal{E}$ Society 37 (1), pp. 85-100. https: //doi.org/10.1177/0163443714549090.

Howe, L. C., Goyer, J. P. and Crum, A. J. (2017). 'Harnessing the placebo effect: exploring the influence of physician characteristics on placebo response'. Health Psychology 36 (11), pp. 1074-1082. https://doi .org/10.1037/hea0000499.

Jang, S. M. (2014). 'Seeking congruency or incongruency online? Examining selective exposure to four controversial science issues'. Science Communication 36 (2), pp. 143-167. https: //doi.org/10.1177/1075547013502733.

Knobloch-Westerwick, S., Johnson, B. K., Silver, N. A. and Westerwick, A. (2015). 'Science exemplars in the eye of the beholder: how exposure to online science information affects attitudes'. Science Communication 37 (5), pp. 575-601. https://doi.org/10.1177/1075547015596367.

Lauricella, S. (2016). 'The ancient-turned-new concept of "spiritual hygiene": an investigation of media coverage of meditation from 1979 to 2014'. Journal of Religion and Health 55 (5), pp. 1748-1762. https://doi.org/10.1007/s10943-016-0262-3.

Lavorgna, A. and Di Ronco, A. (2017). 'Media representations of complementary and alternative medicine in the Italian press: a criminological perspective'. European Journal of Criminology 15 (4), pp. 421-441. https://doi.org/10.1177/1477370817748589.

Lazarsfeld, P. F., Berelson, B. and Gaudet, H. (1944). The people's choice: how the voter makes up his mind in a presidential campaign. New York, NY, U.S.A.: Columbia University Press.

Lewis, M., Orrock, P. and Myers, S. (2010). ‘Uncritical reverence in CM reporting: assessing the scientific quality of Australian news media reports'. Health Sociology Review 19 (1), pp. 57-72. https://doi.org/10.5172/hesr.2010.19.1.057.

Loeb, M., Russell, M. L., Neupane, B., Thanabalan, V., Singh, P., Newton, J. and Pullenayegum, E. (2018). 'A randomized, blinded, placebo-controlled trial comparing antibody responses to homeopathic and conventional vaccines in university students'. Vaccine 36 (48), pp. 7423-7429.

https://doi.org/10.1016/j.vaccine.2018.08.082. 
Lozano Ascencio, C., Piñuel Raigada, J. L. and Gaitán Moya, J. A. (2010). ‘Las verdades implantadas en los titulares de prensa sobre los temas de comunicación. Análisis de la construcción de discursos hegemónicos a partir de las auto-referencias hacia la comunicación'. Razón y palabra 15 (74).

Mathie, R. T., Ramparsad, N., Legg, L. A., Clausen, J., Moss, S., Davidson, J. R. T., Messow, C.-M. and McConnachie, A. (2017). 'Randomised, double-blind, placebo-controlled trials of non-individualised homeopathic treatment: systematic review and meta-analysis'. Systematic Reviews 6 (1). https://doi.org/10.1186/s13643-017-0445-3.

Ministerio de Sanidad, Política Social e Igualdad (2011). Análisis de situación de las terapias naturales. Madrid, Spain. URL: http://www.mscbs . gob.es/novedades /docs/analisisSituacionTNatu. pdf (visited on 20th September 2018).

Negredo, S., Vara, A. and Amoedo, A. (2017). 'Spain'. In: Digital News Report 2017. Ed. by N. Newman, R. Fletcher, A. Kalogeropoulos, D. Levy and R. Nielsen. Oxford, U.K.: Reuters Institute for the Study of Journalism, pp. 92-93. URL: http://www. digitalnewsreport.org/survey/2017/spain-2017/ (visited on 2nd May 2018).

Nissen, N., Johannessen, H., Schunder-Tatzber, S., Lazarus, A. and Weinenhammer, W. (2013). Citizens' need and attitudes towards CAM. CAMbrella project. URL: https://phaidra.univie.ac.at/view/o:264407 (visited on 6th June 2018).

Oreskes, N. (2017). 'Systematicity is necessary but not sufficient: on the problem of facsimile science'. Synthese, pp. 1-25. https://doi.org/10.1007/s11229-017-1481-1.

Pariser, E. (2011). The filter bubble: what the Internet is hiding from you. U.K.: Penguin.

Pray, W. S. (2006). 'Ethical, scientific and educational concerns with unproven medications'. American Journal of Pharmaceutical Education 70 (6), p. 141. https://doi.org/10.5688/aj7006141.

Rowlands, B. A. (2015). 'The emperor's new clothes: media representations of complementary and alternative medicine: 1990-2005'. Doctoral thesis. London, U.K.: City University London. URL: http://openaccess . city .ac.uk/13706/ (visited on 30th May 2018).

Salas, J. (25th April 2018). ‘La homeopatía se venderá en farmacias como medicamento aunque sanidad reconoce que no cura'. El País. URL: https://elp ais.com/elpais/2018/04/25/ciencia/1524649738_998492.html (visited on 3rd May 2018).

Scheufele, D. A. (2000). 'Agenda-setting, priming and framing revisited: another look at cognitive effects of political communication'. Mass Communication and Society 3 (2-3), pp. 297-316. https : //doi .org/10.1207/s15327825mcs0323_07.

Scheufele, D. A. and Tewksbury, D. (2006). 'Framing, agenda setting and priming: the evolution of three media effects models'. Journal of Communication 57 (1), pp. 9-20. https://doi.org/10.1111/j.0021-9916.2007.00326.x.

Shehata, A. and Strömbäck, J. (2013). 'Not (yet) a new era of minimal effects: a study of agenda setting at the aggregate and individual levels'. The International Journal of Press/Politics 18 (2), pp. 234-255. https://doi.org/10.1177/1940161212473831. 
Steuter, E. (2010). 'Consumer advocacy or quack attack? Representations of homeopathy in the media'. Canadian Journal of Media Studies 6 (1), pp. 52-71.

Steuter, E. (2001). 'Pedalling skepticism: media representations of homeopathy as “junk science"'. The Journal of American Culture 24 (3-4), pp. 1-10. https://doi.org/10.1111/j.1537-4726.2001.2403_1.x.

Stocking, S. H. and Holstein, L. W. (2009). 'Manufacturing doubt: journalists' roles and the construction of ignorance in a scientific controversy'. Public Understanding of Science 18 (1), pp. 23-42. https://doi.org/10.1177/0963662507079373.

Sunstein, C. R. (2002). Republic.com. Princeton, NJ, U.S.A.: Princeton University Press.

Vigario, A. (7th December 2017). 'Boiron: “Las ventas han caído un 14\% por los ataques a la homeopatía en España"'. elEconomista.es. URL: http://www.elecono mista.es/sanidad/noticias/8795818/12/17/Boiron-Las-ventas-han-caido - un-14-por-\%201os-ataques-\%20a-la-\%20homeopatia-en-\%20Espana.html (visited on 2nd May 2018).

Vithoulkas, G. (2017). 'An innovative proposal for scientific alternative medical journals'. Journal of medicine and life 10 (3), pp. 197-199.

Weeks, L. C. and Strudsholm, T. (2008). 'A scoping review of research on complementary and alternative medicine (CAM) and the mass media: looking back, moving forward'. BMC Complementary and Alternative Medicine 8 (1). https://doi.org/10.1186/1472-6882-8-43.

Westall, D. (2015). 'A year of El País headlines on childhood obesity (2013)'. Procedia - Social and Behavioral Sciences 198, pp. 509-514. https://doi.org/10.1016/j.sbspro.2015.07.473.

Yel, Ç. (2014). 'The presentation of complementary and alternative medicine (CAM) in the Turkish press'. Procedia - Social and Behavioral Sciences 152, pp. 995-1000. https://doi.org/10.1016/j.sbspro.2014.09.356.

Zion, S. R. and Crum, A. J. (2018). 'Mindsets matter: a new framework for harnessing the placebo effect in modern medicine'. International Review of Neurobiology 138, pp. 137-160. https://doi .org/10.1016/bs.irn.2018.02.002.

\section{Authors}

Lorena Cano-Orón is a PhD Candidate at the University of Valencia (UV) with a predoctoral fellowship awarded by the Spanish Ministry of Economy and Competitiveness. In addition to a BA in Media Communication (UV), she holds an MA in Communication and Journalism Research from the Autonomous University of Barcelona and an MA in Interculturality, Communication and European Studies (UV). She is also a member of the research groups 'Mediaflows' and 'ScienceFlows'. E-mail: Lorena.Cano@uv.es.

Isabel Mendoza-Poudereux holds a PhD in Biotechnology with an European Mention (2013) from the University of Valencia, and a Master's Degree in Creation and Management of Innovative Companies (2015). She has participated in several European research projects, related to Plant Biotechnology and Agriculture, both from a purely technical point of view and tasks related to communication and dissemination of results. She currently compiles her work with the ScienceFlows research group with her freelance work. E-mail: Isabel.Mendoza@uv.es. 
Carolina Moreno-Castro. Full Professor of Journalism in the Department of Theory of Language and Communication at the University of Valencia, Spain. She has published a number of works about the representativeness, the social treatment, and perception of health, the science, the technology and the environment on media. Furthermore, she has led several research projects about the risk communication and the science communication. Currently, she is a member of the board of directors of the Spanish Association of Science Communication (AECC). E-mail: Carolina.Moreno@uv.es.

\section{How to cite}

Cano-Orón, L., Mendoza-Poudereux, I. and Moreno-Castro, C. (2019). 'The rise of skepticism in Spanish political and digital media contexts'. JCOM 18 (03), A01. https://doi.org/10.22323/2.18030201. 